\title{
Uji efek antibakteri ekstrak kulit kayu manis (Cinnamomum burmannii) terhadap Escherichia coli dan Streptococcus pyogenes
}

\author{
${ }^{1}$ Noviano B. Repi \\ ${ }^{2}$ Christi Mambo \\ ${ }^{2}$ Jane Wuisan
}

\author{
${ }^{1}$ Kandidat Skripsi Fakultas Kedokteran Universitas Sam Ratulangi Manado \\ ${ }^{2}$ Bagian Farmakologi dan Terapi Fakultas Kedokteran Universitas Sam Ratulangi Manado \\ Email: bennyrepi45@gmail.com
}

\begin{abstract}
Cinnamon (Cinnamomum burmannii) is a natural substance that has been known as one of the spices, but later known as traditional medicine. Cinnamon bark contains several antibacterial compounds, such as eugenol and cinnamaldehyde. There were two species of bacteria used in this study, Escherichia coli and Streptococcus pyogenes. These bacteria represent negative Gram bacteria and positive gram bacteria. The study aimed to determine antibacterial effect of cinamon bark againts E.coli and S.pyogenes by measuring the diameters of the inhibition zones. Cinamon bark samples were taken from Kaneyan, South Minahasa, and then be extracted by maceration using $80 \%$ etanol. The results showed that the total diameter of the inhibitory zone of Cinamon bark extract against E.coli was $43 \mathrm{~mm}$ with an average of $14,3 \mathrm{~mm}$, and the total diameter of the inhibitory zone against S.pyogenes was 75 $\mathrm{mm}$ with an average of $25 \mathrm{~mm}$. Conclusion: Cinamon bark extract had antibacterial effect against E Escherichia coli and Streptococcus pyogenes.
\end{abstract}

Keywords: cinamon bark, escherichia coli, streptococcus pyogenes,antibacterial effect.

\begin{abstract}
Abstrak: Kayu manis (Cinnamomum burmannii) merupakan bahan alami yang selama ini hanya dikenal sebagai bumbu dalam masakan, tetapi ternyata memiliki khasiat obat. Kulit kayu manis mengandung beberapa senyawa yang bersifat antibakteri, seperti eugenol dan cinnamaldehyde. Bakteri Escherichia coli dan Streptococcus pyogenes merupakan bakteri yang digunakan didalam peneilitian ini. Kedua bakteri ini mewakili bakteri Gram negatif dan positif. Penelitian ini bertujuan untuk mengetahui efek antibakteri kulit kayu manis terhadap $E$. coli dan S. pyogenes, yang dinilai dari besarnya zona hambat yang terbentuk. Jenis penelitian ini eksperimental dengan metode sumuran Kirby-Bauer. Sampel kulit kayu manis diambil dari daerah Kaneyan Kabupaten Minahasa Selatan, kemudian diekstraksi dengan metode maserasi menggunakan pelarut etanol $80 \%$. Hasil penelitian memperlihatkan diameter zona hambat total dari ekstrak kulit kayu manis terhadap E. coli sebesar $43 \mathrm{~mm}$ dengan rerata $14,3 \mathrm{~mm}$, dan terhadap $S$. pyogenes diameter zona hambat total $75 \mathrm{~mm}$ dengan rerata $25 \mathrm{~mm}$. Simpulan: Ekstrak kulit kayu manis memiliki efek antibakteri dalam menghambat pertumbuhan Escherichia coli dan Streptococcus pyogenes

Kata kunci: kulit kayu manis, Escherichia coli, Streptococcus pyogenes, antibakteri
\end{abstract}

Indonesia merupakan salah satu negara yang kaya akan keanekaragaman hayati. Dari total 28.000 spesies tumbuhan obat di Indonesia, telah diidentifikasi sebanyak 1.845 memiliki sifat seperti obat. $^{1}$ Penggunaan tumbuhan sebagai obat untuk penyembuhan penyakit telah banyak diteliti. Obat tradisional memang bermanfaat bagi kesehatan dan kini digencarkan penggunaannya karena lebih mudah dijangkau masyarakat, baik harga maupun ketersediaannya. Salah satu obat 
tradisional yang dikenal adalah tumbuhan kayu manis. Manfaat mengonsumsi kayu manis antara lain dapat menurunkan kolesterol, menurunkan kadar gula darah, anti jamur, anti virus, anti parasit, antiseptik dan sebagai antibakteri. ${ }^{2}$ Masalah resistensi mikroorganisme terhadap antibiotik ditemukan pertama kali pada tahun 1980-an dan telah menjadi permasalahan yang sangat penting bagi dunia kedokteran saat ini. Tingginya penggunaan antibiotik menjadi pemicu utama munculnya resistensi. ${ }^{3}$

Bakteri Escherichia coli (E. coli) merupakan bakteri Gram negatif dan biasanya terdapat dalam jaringan intestinal. Manifestasi klinis dari infeksi E.coli ini tergantung pada daerah infeksi dan tidak dapat dibedakan dari gejala yang disebabkan oleh bakteri lainnya. ${ }^{4}$ Streptococcus pyogenes (S. pyogenes) adalah bakteri Gram positif yang merupakan salah satu patogen yang banyak menginfeksi manusia. Diperkirakan 5-15\% individu normal memiliki bakteri ini dan biasanya terdapat pada saluran pernafasan, namun tidak menimbulkan gejala penyakit. $^{5}$

Penelitian ini bertujuan untuk mengetahui efek antibakteri kulit kayu manis (Cinnamomum burmannii) terhadap Escherichia coli dan Streptococcus pyogenes.

\section{METODE PENELITIAN}

Jenis pnelitian ini eksperimental laboratorium. Penelitian ini dilakukan di Laboratorium Farmakologi dan Terapi Fakultas Kedokteran Universitas Sam Ratulangi dari bulan September 2015 sampai Januari 2016. Sampel penelitian ini ialah kulit kayu manis yang diambil dari desa Kaneyan, Kabupaten Minahasa Selatan.

Bahan bahan yang digunakan antara lain: kulit kayu manis, bakteri E. coli dan $S$. pyogenes, Brain heart infusion broth (BHIB), Nutrien agar (NA), Muller-Hinton agar (MHA), Amoksisilin @500 mg, Akuades, dan etanol $80 \%$.
Pembuatan ekstrak kulit kayu manis, dilakukan dengan cara maserasi. Pembuatan Media Peremajaan yaitu Nutrien Agar (NA), Brain Heart Infusion Broth (BHI-B), media MHA, dan larutan baku McFarland, suspensi, dan dilanjutkan dengan pengujian bakteri

Metode pengujian yang digunakan dalam penelitian ini ialah metode modifikasi Kirby-Bauer dengan menggunakan sumuran.

Pengukuran zona hambat dilakukan setelah 24 jam masa inkubasi (Gambar 1). Zona bening merupakan petunjuk kepekaan bakteri terhadap bahan antibakteri yang digunakan sebagai bahan uji dan dinyatakan dengan diameter zona hambat. Penilaian zona hambat menurut Susanto, Sudrajat dan Ruga pada tahun 2012, dikategorikan menjadi lemah $(\leq 5 \mathrm{~mm})$, sedang (6-10 mm), kuat (11-20 mm), dan sangat $\operatorname{kuat}(\geq 21 \mathrm{~mm}) .{ }^{15}$ Diameter zona hambat dapat diukur dengan rumus:

$$
\frac{\left(D_{v}-D_{S}\right)+\left(D_{h}-D_{S}\right)}{2}
$$

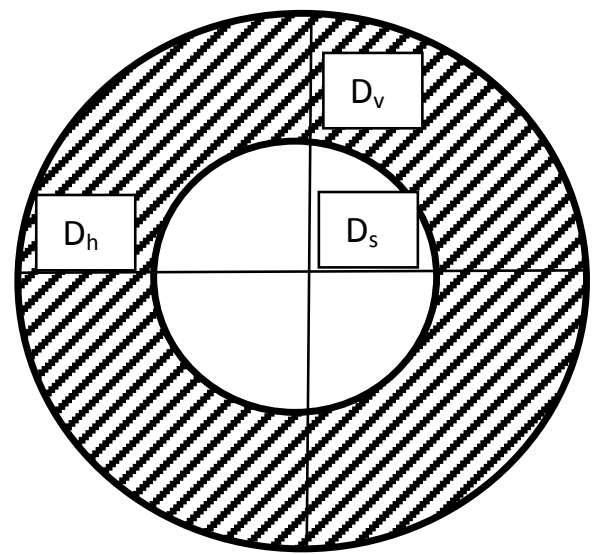

Gambar 1. Pengukuran diameter zona hambat. Dv: DiameterVertikal; $\mathrm{D}_{\mathrm{s}}$ Diameter sumur; $\mathrm{D}_{\mathrm{h}}$ : Diameter horizontal ; hambat

\section{HASIL PENELITIAN}

Hasil pengukuran daya hambat ekstrak kulit kayu manis (Cinnamomum burmanii) terhadap bakteri $S$. pyogenes dan E. coli setelah diinkubasi terlihat pertumbuhan bakteri menjauhi sumur artinya terdapat 
efek antibakteri dari ekstrak kulit kayu manis (Cinnamomum burmanii) terhadap bakteri S. pyogenes dan E. coli (Tabel 1 dan 2).

Tabel 1 menunjukkan total diameter zona hambat ekstrak kulit kayu manis terhadap bakteri $S$. pyogenes pada tiga cawan petri ialah $75 \mathrm{~mm}$ dengan rerata 25 mm. Tabel 2 menunjukkan total diameter zona hambat ekstrak kulit kayu manis terhadap bakteri E.coli pada tiga cawan petri adalah $43 \mathrm{~mm}$ dengan rerata $14,3 \mathrm{~mm}$.

Tabel 1. Diameter zona hambat ekstrak kulit kayu manis terhadap bakteri S.pyogenes.

\begin{tabular}{cccc}
\hline Cawan $\begin{array}{c}\text { Ekstrak Kulit Kayu Manis } \\
\text { Petri }\end{array}$ & $\begin{array}{c}\text { Diameter } \\
\text { Horizontal } \\
(\mathrm{mm})\end{array}$ & $\begin{array}{c}\text { Diameter } \\
\text { Vertikal } \\
(\mathrm{mm})\end{array}$ & $\begin{array}{c}\text { Diameter } \\
\text { zona } \\
\text { Hambat } \\
(\mathrm{mm})\end{array}$ \\
\cline { 2 - 4 } I & 19 & 20 & 13,5 \\
II & 52 & 35 & 37,5 \\
III & 31 & 29 & 24 \\
Total & & & 75 \\
Rerata & & & 25 \\
\hline
\end{tabular}

Tabel 2. Diameter zona hambat Ekstrak kulit kayu manis terhadap E.coli

\begin{tabular}{cccc}
\hline Cawan & \multicolumn{3}{c}{ Ekstrak Kulit Kayu Manis } \\
\cline { 2 - 4 } Petri & $\begin{array}{c}\text { Diameter } \\
\text { Horizontal } \\
(\mathrm{mm})\end{array}$ & $\begin{array}{c}\text { Diameter } \\
\text { Vertikal } \\
(\mathrm{mm})\end{array}$ & $\begin{array}{c}\text { Diameter } \\
\text { zona } \\
\text { Hambat } \\
(\mathrm{mm})\end{array}$ \\
\cline { 2 - 4 } I & 20 & 25 & 16,5 \\
II & 12 & 21 & 10,5 \\
III & 13 & 15 & 16 \\
Total & & & 43 \\
Rerata & & & 14,3 \\
\hline
\end{tabular}

\section{BAHASAN}

Penelitian ini merupakan uji eksperimental untuk mengetahui efek antibakteri pada ekstrak kulit kayu manis dalam menghambat pertumbuhan bakteri $S$. pyogenes dan E. coli. Dalam penelitian ini digunakan metode sumuran KirbyBauer. Metode ini membuat ekstrak kulit kayu manis dapat berdifusi secara maksimal pada media pertumbuhan bakteri, melalui lubang atau sumur sampai ke dasar media.

Pada penelitian ini, akuades digunakan sebagai kontrol negatif karena merupakan larutan pengencer pada kontrol positif maupun ekstrak kulit kayu manis. Akuades sebagai kontrol negatif membuktikan bahwa larutan pengencer tidak berpengaruh sebagai antimikroba.

Amoksisilin digunakan sebagai kontrol positif untuk dibandingkan efek antibakteri antara obat antibakteri dengan ekstrak kulit kayu manis. Pemilihan amoksisilin sebagai kontrol positif karena amoksisilin merupakan antibiotik spektrum luas. ${ }^{6}$ Pada penelitian ini, untuk bakteri $S$. pyogenes dan E. coli didapatkan hasil adanya zona hambat yang terbentuk disekitar sumur.

Penelitian mengenai efek antibakteri dari ekstrak kulit kayu manis ini sudah pernah dilakukan sebelumnya namun dengan bakteri dan cara ekstraksi yang berbeda. Nisa $\mathrm{LC}^{7}$ meneliti aktivitas antibakteri kulit kayu manis dengan menggunakan cara esktraksi yang berbeda terhadap E. coli dan Staphylococcus aureus (S. aureus). Hasil penelitiannya menunjukkan hasil ekstraksi infundasi lebih mampu menghambat pertumbuhan bakteri E. coli dan S. aureus. Demikian juga dengan hasil penelitian yang dilakukan ini yaitu dengan menggunakan metode ekstraksi maserasi didapatkan terbentuknya zona hambat yang menunjukkan bahwa ekstrak kulit kayu manis dapat menghambat pertumbuhan bakteri $S$. pyogenes dan E. coli.

Penelitian mengenai kayu manis Cinnamomum burmannii, pernah juga dilakukan oleh Chandurkar et al. ${ }^{8}$ yang mendapatkan bahwa minyak batang kayu manis memiliki sensitivitas pada mikroba $S$. pyogenes dan $P$. aeruginosa.

Pada penilaian zona hambat menurut Susanto, Sudrajat, dan Ruga (2012), diameter zona hambat $\leq 5 \mathrm{~mm}$ dikategorikan lemah; zona hambat 6-10 mm dikategorikan sedang; zona hambat 11-20 mm dikategorikan kuat, zona hambat $\geq 21$ mm dikategorikan sangat kuat. ${ }^{9}$

Diameter dari zona hambat yang terbentuk pada daerah sekitar sumur yang 
diberikan ekstrak kulit kayu manis dapat menjadi tolok ukur kekuatan dari senyawa yang terkandung dalam ekstrak kulit kayu manis. Semakin panjang diameter zona hambat sekitar sumur, semakin kuat pula senyawa aktif yang menghambat pertumbuhan bakteri. Rerata zona hambat yang terbentuk yaitu $25 \mathrm{~mm}$ pada bakteri S. pyogenes dan $14,3 \mathrm{~mm}$ pada bakteri $E$. coli. Berdasarkan kategori zona hambat tersebut, maka ekstrak kulit kayu manis tergolong sangat kuat dalam menghambat bakteri $S$. pyogenes, serta tergolong kuat dalam menghambat bakteri E. coli.

Berdasarkan diameter zona hambat yang terbentuk, diameter zona hambat dari bakteri $S$. pyogenes lebih besar dibandingkan dengan bakteri E. coli. Kemungkinannya karena E.coli (Gram negatif) memiliki dinding sel yang dilapisi lipopolisakarida yang lebih banyak sehingga kandungan lipidnya tinggi serta memiliki sifat permeabilitas yang tinggi. ${ }^{10}$ Berbeda halnya dengan $S$. pyogenes (bakteri Gram positif) yang memiliki strukutur selubung sel yang relatif sederhana yakni membran sitoplasma dan lapisan peptidoglikan yang tebal. Hal ini yang menyebabkan bakteri Gram positif lebih rentan terhadap bahan antimikrobial. $^{11}$ Dengan demikian bakteri $S$. pyogenes lebih mudah ditembus dinding selnya oleh ekstrak kulit kayu manis.

Berdasarkan hasil penelitian didapatkan bahwa ekstrak kulit kayu manis memiliki kemampuan sebagai antibakteri terhadap S. pyogenes dan E. coli. Hal ini disebabkan adanya kandungan zat aktif dalam kulit kayu manis yang diduga memiliki efek antibakteri yaitu eugenol. Eugenol juga terdapat dalam minyak cengkeh, dan minyak pala. Pada temperatur normal, eugenol kental dan berwarna kuning pucat, berminyak dengan rasa cengkeh yang kuat dan memiliki aroma panas yang khas. Eugenol sedikit larut dalam air dan mudah larut dalam pelarut organik. Eugenol juga mempunyai efek antioksidan, anti kanker dan efek anestesi. ${ }^{12}$

Eugenol mengandung struktur senyawa cincin benzena yang mengandung gugus hidroksil memiliki khasiat antibakteri bahkan ketika diencerkan lebih dari 2000 kali. Mekanisme antibiotik eugenol dan bumbu lainnya ialah dengan menghancurkan dinding sel, juga merusak membran plasma dan protein membran serta mengeluarkan isi sel. Hidrofobisitas eugenol merupakan faktor penting yang memengaruhi aktivitas antibakteri. Sifat hidrofobisitas eugenol dapat memisahkan lipid dari membran sel dan mitokondria bakteri dan mengubah struktur untuk meningkatkan penetrasi melalui membran sel. Eugenol juga memiliki aktivitas antibiotik karena dapat memblokir aliran elektron dan transpor aktif, serta menyebabkan pembekuan isi sel. ${ }^{12}$

\section{SIMPULAN}

Dari hasil penelitian dan bahasan dapat disimpulkan bahwa kayu manis (Cinnamomum burmannii) memiliki efek antibakteri terhadap bakteri Escherichia coli dan Streptococcus pyogenes.

\section{SARAN}

1. Diharapkan dapat dilakukan penelitian lebih lanjut mengenai konsentrasi dan daya hambat minimal dari ekstrak kulit kayu manis

2. Perlu dilakukan penelitian lanjut mengenai efek antibakteri ekstrak kulit kayu manis terhadap jenis bakteri lainnya

3. Perlu dilakukan penelitian lebih lanjut menggunakan bakteri yang diisolasi langsung dari bagian tubuh pasien yang menderita infeksi agar dapat mengetahui manfaat ekstrak kulit kayu manis in vivo.

\section{UCAPAN TERIMA KASIH}

Ucapan terima kasih disampaikan pada dr. Edward Nangoy, MARS, SpFK, Drs. Engerlbertus Saerang, Apt, dan semua pihak yang baik secara langsung maupun tidak langsung telah menumbuhkan ide atau gagasan dalam pemikiran penulis.

\section{DAFTAR PUSTAKA}

1. Bahtera E. Terbesar kedua di dunia, 
keanekaragaman hayati Indonesia baru tergarap 5\%. 2015 Okt 19 [cited 2015 Oct 22]. Available from: http://news.unpad.ac.id/?p=36173.

2. Vangalapati M, Satya SN. Prakash SDV, Avanigadda S. A review on pharmacological activities and clinical effects of cinnamon species. Research journal of pharmaceutical, biological and chemical. 2012; 3:6579.

3. Lembaga pengkajian dan penelitian ilmu kesehatan masyarakat fakultas kedokteran UI. Resistensi bakteri terhadap antibiotik: masalah klasik yang tak kunjung selesai. 2012 Jul 07. [cited 2015 Oct 22]. Available from:http://pp.fk.ui.ac.id/author/admi $\mathrm{n} /$.

4. Noviana H. Pola kepekaan antibiotika escherichia coli yang diisolasi dari berbagai spesimen klinis. Jurnal Kedokteran Trisakti. 2004;23. [cited 2015 Okt 19]. Available from:http://www.univmed.org/wpcon tent/uploads/2011/02/Hera.pdf.

5. Kusuma SAF. Strepococcus pyogenes. [cited 2015 Oct 2015]. Available from: http://pustaka.unpad.ac.id/ wpcontent/uploads/2011/09/pustaka_ unpad_streptococcus -pyogenes.pdf.

6. Istiantoro YH, Gan VHS. Penisilin, sefalosporin dan antibiotik betalaktam lainnya. In: Gan S, Gunawan, Rianto Setiabudy, Nafrialdi, Elysabeth, editors. Farmakologi dan Terapi (5th ed). Jakarta: Badan penerbit FKUI, 2012; p. 664-73.

7. Nisa LC. Aktivitas antibakteri kulit kayu manis (Cinnamomum burmanni) dengan cara ekstraksi yang berbeda terhadap Escherichia coli dan Staphylococcys aureus. [cited 2016 Jan 26]. Available from: https://www.google.co.id/url?sa=t\&rc $\mathrm{t}=\mathrm{j} \& \mathrm{q}=\&$ esrc $=\mathrm{s} \&$ source $=$ web\&cd $=2$ \&cad=rja\&uact $=8 \&$ ved=0ahUKEwill bfD2MbKAhUTBo4KHVffCUQQFg ghMAE\&url=http\%3A\%2F\%2Feprin ts.ums.ac.id\%2F29751\%2F21\%2FN ASKAH_PUBLIKASI.pdf\&usg=AF QjCNGfvaN5MdeD6L8uPCt9HT4R VBvTpw\&sig2=8sZxM06AQgD76M OPSot6XA.

8. Chandukar $P, N$ Tripathi $\mathbf{N}$, Choudary A, Murab T. Antibacterial properties of cinnamon stick oil with special reference to Streptococcus pyogenes and Pseudomonas aeruginosa. International Journal of Current Microbiology and Applied Sciences. 2014;3:177-8.

9. Susanto, Sudrajat D, Ruga R. Studi kandungan bahan aktif tumbuhan meranti merah (Shorea leprosula Miq) sebagai sumber senyawa antibakteri. Mulawarmnan Scientific. 2012;11(2):181-90.

10.Masduki I. Efek Antibaktri Ekstrak Biji Pinang (Area catechu) terhadap $S$. aureus dan E. coli in vitro. Cermin Dunia Kedokteran. 1996;109:21-24

11.Brooks GF, Butel JS, Morse SA, editors. Jawetz, Melnick \& Adelberg Mikrobiologi Kedokteran (25th ed). Jakarta: EGC, 2007; p. 206-11.

12.KongXJ, Liu XW. Jianyong LI. Yang YY. Advanced in Pharmacological Research of Eugenol. [cited 2016 Jan 02]. Available from: https://www.google.co.id/url?sa=t\&rc $\mathrm{t}=\mathrm{j} \& \mathrm{q}=\&$ esrc $=\mathrm{s} \&$ source $=$ web\& $\mathrm{cd}=3$ \&cad=rja\&uact $=8 \&$ ved $=0$ ahUKEwiQ 5O3I0NjKAhWICY4KHSpeCFUQF ggoMAI\&url=http\%3A\%2F\%2Fww w.stmconnect.com\%2Fsites\%2Fdefau lt\%2Ffiles\%2F20131023205704.pdf \&usg=AFQjCNHBqZ_MoJQivAPdh 5NHxqG4GySSg\&sig2=fSVFs4JGv3TCxRV_V_ $-\mathrm{yCw}$. 